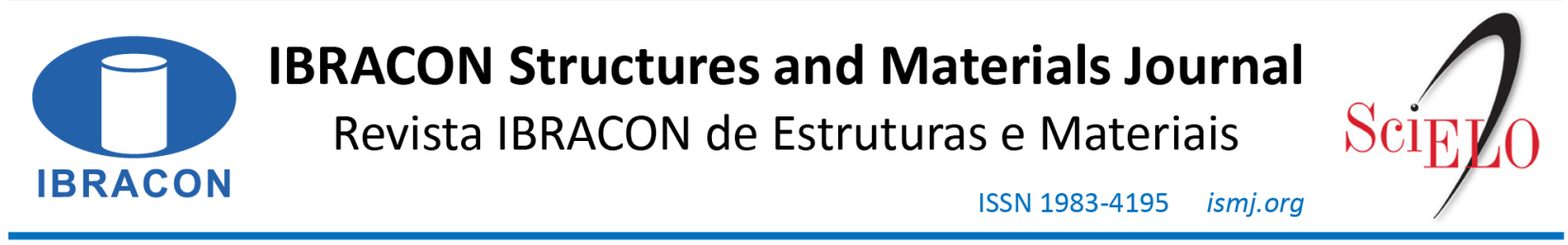

ORIGINAL ARTICLE

\title{
Optimized design of concrete-filled steel columns
}

\section{Dimensionamento otimizado de pilares mistos de aço preenchidos com concreto}

\author{
Jéssica Salomão Lourenção ${ }^{\mathrm{a}}$ (i) \\ Paulo Augusto Tonini Arpini ${ }^{\mathrm{a}}$ (D) \\ Gabriel Erlacher $^{\mathrm{a}}$ (D) \\ Élcio Cassimiro Alves ${ }^{\mathrm{a}}$ (it)
}

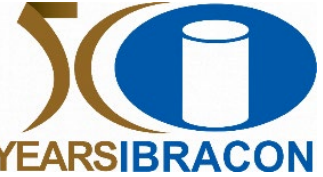

${ }^{a}$ Universidade Federal do Espírito Santo - UFES, Departamento de Engenharia Civil, Vitória, ES, Brasil

Received 13 October 2020

Accepted 16 April 2021

\begin{abstract}
The objective of this paper is to present the formulation of the optimization problem and its application to the design of concrete-filled composite columns with and without reinforcement steel bars, according to recommendations from NBR 8800:2008, NBR 16239:2013 and EN 1994-1-1:2004. A comparative analysis between the aforementioned standards is performed for various geometries considering cost, efficiency and materials in order to verify which parameters influence the solution of the composite column that satisfies the proposed problems. The solution of the optimization problem is obtained by using the genetic algorithm method featured in MATLAB's guide toolbox. For the examples analyzed, results show that concretes with compressive strength greater than 50MPa directly influence the solution of the problem regarding cost and resistance to normal forces.
\end{abstract}

Keywords: composite filled columns, optimization, hollow sections, genetic algorithm.

Resumo: O objetivo deste trabalho é apresentar a formulação do problema de otimização e suas aplicações para pilares mistos de aço preenchidos com concreto, com e sem armadura, segundo as normas ABNT NBR 8800:2008, ABNT NBR 16239:2013 e EN 1994-1-1:2004. Uma análise comparativa entre as normas supracitadas e entre as geometrias estudadas em termos de custo, eficiência, contribuição dos materiais na solução é realizada de modo a verificar os parâmetros que influenciam na solução do pilar misto que satisfaça os problemas propostos. A solução do problema de otimização, é obtida através do Método do Algoritmo Genético disponível no toolbox do Matlab. Para os exemplos analisados, os resultados apontam que os concretos com resistência acima de 50MPa influenciam diretamente na solução do problema tanto no custo, quanto no esforço normal resistente.

Palavras-chave: pilares mistos preenchidos, otimização, perfis tubulares, algoritmo genético.

How to cite: J. S. Lourenção, P. A. T. Arpini, G. Erlacher, and E. C. Alves, “Optimized design of concrete-filled steel columns,” Rev. IBRACON Estrut. Mater., vol. 15, no. 1, e15102, 2022, https://doi.org/10.1590/S1983-41952022000100002

\section{INTRODUCTION}

When filled with concrete and subjected to compression, tubular steel profiles are commonly referred to as composite filled columns. The combined use of steel and concrete in structural elements is widely used in civil construction since it presents a number of advantages such as increased load bearing capacity, dismissal of wooden formwork during construction and protection against fire and corrosion.

Composite filled columns usually employ steel profiles with rectangular (RHS), square (SHS) or circular (CHS) hollow sections as outer casing, with or without the addition of longitudinal rebar, depending on load type and magnitude. In Brazil, procedures for the design of concrete-filled composite columns are currently prescribed by ABNT NBR 8800 [1] - Design of steel structures and steel-concrete composite structures. However, particularities concerning the structural behavior of tubular steel profiles resulted in the publication of ABNT NBR 16239 [2] - Design of steel structures and 
steel-concrete composite structures featuring tubular profiles, by the Brazilian Association of Technical Standards. This standard was created to provide specific equations for the design of composite filled columns, since ABNT NBR 8800 [1] only presents one curve for determining the reduction factor associated with axial strength as a function of slenderness, for all types of composite columns, without distinction, which considerably underestimates the ultimate strength of composite filled columns. In Europe, the design of composite columns is standardized by EN 1994-1-1 [3] - Design of steel-concrete composite columns - Part 1-1: General rules and rules for buildings.

Since numerous cross-section geometries are available for composite columns, it may be challenging to define the best and most cost-efficient option, that is, the optimum geometry for a given load configuration and other parameters that influence the ultimate strength of the structural element. Generally, the variables bearing the most influence on the final cost of composite filled columns are: the cost of concrete, which depends on compressive strength, the cost of the structural profile and the cost of longitudinal rebar. It is highlighted here that structural connections and architectural aspects are not included in the scope of this research. Furthermore, costs attributed to labor are directly proportional to the topology of the structure. Previous studies indicate that the use of optimization techniques during structural design results in a $15 \%$ to $20 \%$ reduction in weight and/or dimensions of structural elements [4], [5].

Optimal cross-sections may be obtained by inserting structural optimization techniques in computer programs that perform iterative calculations, in which design variables are updated until the minimum cost for a given column is determined. This procedure must also account for structural safety and stability criteria defined by design standards. However, authors such as Santoro and Kripka [6] and Tormen et al. [7] stress that using financial cost as the only optimization parameter is not enough to arrive at an optimum solution, additional variables such as $\mathrm{CO}_{2}$ emissions attributed to the life-cyle of materials may also be a preponderant factor for determining the best result.

This research aims to present the formulation for the design optimization of concrete-filled composite columns with and without longitudinal rebar, in addition to comparing results between the design standards ABNT NBR 8800 [1], ABNT NBR 16239 [2] and EN 1994-1-1 [3]. Numerical examples are presented, and results for different standards and geometries are compared, considering the structure at ambient temperature. The program was developed with the Guide tool and the optimization problem was solved using the Genetic Algorithm toolbox from Matlab. Finally, the results obtained are used for determining which parameters bear the most influence on the final cost and efficiency of the structures analyzed herein.

\section{BIBLIOGRAPHY REVIEW}

In recent decades, concrete-filled steel-concrete composite columns have been the subject of numerous experimental, theoretical and numerical studies.

De Nardin [8] performed experiments to assess the influence of cross-section geometry and thickness of the tubular profile on the axial strength of composite filled columns. The study included SHS, CHS and RHS profiles filled with concrete. Results obtained for ultimate strength were similar to those observed experimentally, even without considering concrete confinement effects.

Duarte et al. [9] compared the axial strength of composite columns filled with conventional and rubberized concrete. Both types of column present similar results concerning the total energy absorbed, but the rubberized concrete increased the ductility of structural elements and reduced environmental impacts by using discarded tires and less natural aggregates.

Dundu [10], analyzed the behavior of 24 steel-concrete composite columns axially compressed until structural failure. Specimens were divided into two groups, with differences in the strength of steel and concrete, as well as different column diameters. The first group featured the use of concrete with higher compressive strength, and presented the buckling of the gross composite section as an ultimate limit state. The second group was characterized by columns with larger diameter and stronger steel, reaching structural failure by concrete crushing and yielding of the steel section. Experimental results were observed to be conservative when compared to strength predictions from EN 1994-1-1 [3].

Gajalakshmi and Helena [11] performed an experimental analysis of the damage observed in composite filled columns subjected to quasi-static loading. The tests were divided into two phases: During the first phase, specimens were subjected to loads with variations in amplitude and constant axial forces while the second phase featured constant amplitudes. Results show an increase in the ductility of the structure, which was able to absorb twice the amount of energy in some cases.

Kuranovas et al. [12] analyzed experimental data from 1303 concrete-filled steel columns. Specimens featured CHS and RHS subjected to compression and to axial-compression and bending-. Experimental results were compared to strength predictions from EN 1994-1-1 [3], and good agreement was observed when compared to the literature for concretes with compressive strength of up to $75 \mathrm{MPa}$, value in which the ultimate load obtained experimentally is observed to be inferior and thus more conservative than results obtained using Eurocode.

Caldas et al. [13] performed a study to assist in the review of ABNT NBR 8800:1986 and presented procedures for the design of concrete-filled steel-concrete composite columns subjected to combined bending moment and axial force. 
The study was based on the European standard EN 1994-1-1 [3] and the American standard ANSI/AISC 360-05, both of which served as the theoretical basis for the proposal of two design procedures for the review. Authors compared the results obtained with the proposed models to a finite element analysis, and observed acceptable agreement. Furthermore, design model I is observed as more conservative than design model II since the former is a simplified formulation originally proposed for the design of steel structures. This behavior becomes more evident when both models are applied to columns with relatively smaller slenderness and lower values of steel contribution factors.

Oliveira [14] studied the behavior of circular composite filled columns by performing a theoretical-experimental analysis to assess the influence of compressive strength of concrete, column slenderness, tube thickness and load type on the ultimate strength of the structural elements. Experimental tests were performed in 64 columns subjected to pure compression. Results were compared to design standards and show that the numerical model accurately represents the behavior of the columns, but the ultimate strengths obtained numerically are lower than those observed experimentally.

Papavasileiou et al. [15] investigated the cost-benefit ratio of concrete-encased composite columns and composite filled columns as an alternative for the use of steel I-beam columns. A comparison between column types was performed using structural optimization, seeking to minimize financial costs and safety restrictions imposed by EN 1993-1-1:2005 and EN 1994-1-1:2004. Optimized results favor the use of composite elements in structural systems that require an increased number of columns. The authors also indicate that fire-resistance is amplified when composite columns are used.

Aghdamy et al. [16] presented a study on the design of concrete-filled composite columns subjected to axial and lateral impact loads. The model proposed by the authors accounts for the effects attributed to concrete confinement. The ratio between tube thickness and diameter, slenderness ratio and impact speed were observed as the governing factors for determining ultimate strength.

Tao et al. [17] evaluated the effects of concrete confinement in concrete-filled tubular columns subjected to axial compression. The analysis was performed by introducing novel functions for determining parameters related to confined concrete. The proposed model was observed as more versatile than other experimental approaches. Adjustments of the model are also proposed in order to allow the consideration of concretes with higher compressive strengths.

Thai et al. [18], proposed a hybrid elasto-plastic model to show the effects of considering initial local geometric imperfections and residual stresses in second order analyses of the structure.

Wang et al. [19] elaborated simplified systems to determine the axial strength of steel-concrete composite tubular columns. The ultimate strength, axial stiffness and yield strength of steel of the structural elements was determined via finite element analysis. The numerical models proved useful for evaluating the ductility and strain capacity of structural elements.

Improvements introduced by ABNT NBR 16239 [2] in relation to ABNT NBR 8800 [1] are detailed by Canales [20], since the most recent standard prescribes a specific procedure in item $1.3 \mathrm{~b}$ for the design of bars subjected to compression and featuring seamless hot-rolled tubular steel profiles or heat treated profiles with and without longitudinal welds. The new methodology allows a more efficient and economical design of composite filled columns if compared to ABNT NBR 8800 [1]. The author provided spreadsheets to assist in the design of steel tubular columns and composite filled columns. Results show that the improvements detailed on the most recent standard directly impacts the magnitude of the compressive design strength of columns, since the design procedures from ABNT NBR 8800 [1] are more efficient for cases in which the steel profile significantly contributes for the ultimate strength of the composite column.

Studies on the design optimization of steel-concrete composite filled columns are relatively recent. Among existing research papers, Papavasileiou and Charmpis [21] present a cost-optimization study of steel-concrete composite beams and columns in multi-story buildings subjected to seismic loading. The authors implemented a probabilistic optimization method similar to Genetic Algorithms called "Evolution Strategies". The method proved to be efficient when applied to practical scenarios.

Lourenção and Alves [22] used Matlab to develop a formulation for minimizing the total cost of composite filled columns, following prescriptions from ABNT NBR 8800 [1] and from ABNT NBR 16239 [2]. Solutions were obtained using the interior point method and sequential quadratic programming, considering tube dimensions as continuous variables. Results indicated a significant reduction in the total cost of composite filled columns in comparison to other methods available in the pertinent literature.

Pekbey et al. [23] performed analyses to determine column shapes able to bear the highest ultimate load without inducing buckling, considering column height and volume as problem variables. As such, optimization procedures were developed to maximize the lowest eigenvalue via analyzing the total volume of the composite column. The optimization model was validated by comparing results with a numerical analysis performed with Ansys and experimental examples. Optimized results showed that the experimental data used as reference provided inaccurate indications of optimal cross-section.

Brauns and Skadins [24] proposed a formulation of the optimization problem for concrete filled columns aimed at minimizing the stress distribution on the internal walls and along the thickness of the profile. They concluded that the 
optimization of working conditions and cross section area of a composite structure, as well as the prevention of failure due to insufficient thickness of structural steel and fire may be obtained by using appropriate strengths for concrete and steel.

Despite the publication of numerous studies on composite filled columns in recent years, optimization analyses using genetic algorithms (GA) and featuring a comparison between prescriptions from ABNT NBR 8800 [1], ABNT NBR 16239 [2] and EN 1994-1-1 [3] are not observed in the literature. Table 1 presents the most notable experimental and numerical studies focused on the design of composite filled columns. The bottom line of the table presents the main characteristics of the optimization procedure proposed in this paper, included in order to provide an overview of the main differences in comparison with other methods, namely the inclusion of genetic algorithm optimization based on the aforementioned standards, as well as the consideration of high strength concrete.

\subsection{Genetic Algorithm Method}

The genetic algorithms proposed by John Holland during the 60's are mathematical models inspired by the principles of Darwinian natural selection, in which, given an initial population, new populations are created by genetic crossing, and the most suitable individuals are selected as the solution of a given problem.

Examples of GA applied to structural engineering include the optimization of steel-concrete composite beams [25], spatial steel frames [4], [26], railway viaducts [27], bridges [28]-[30] and life-cycle analysis of bridges [31]. The present work uses the Genetic algorithm native to the Optimization Toolbox ${ }^{\mathrm{TM}}$ from Matlab 2016a, namely the function $g a$. The initial population contains 120 individuals and the following, 60. The rate of elite individuals and crossing of the intermediate type are 0,05 and 0,8 , respectively, whereas the mutation rate is random. The GA is performed primarily with an entirely random initial population, thereby obtaining an optimal local response. Subsequently, the algorithm is executed again with the previously obtained answer added to the initial population. More details can be found on the Matlab documentation.

Table 1 - Most notable studies on composite columns.

\begin{tabular}{|c|c|c|c|c|c|c|c|c|c|}
\hline Author & 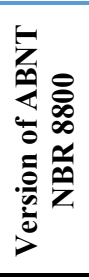 & 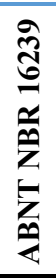 & $\frac{\frac{7}{7}}{\frac{7}{2}}$ & 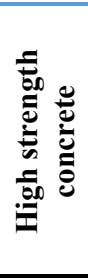 & 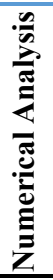 & 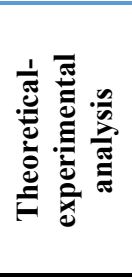 & 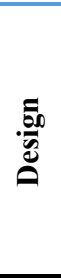 & 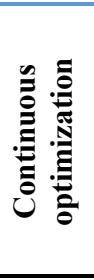 & 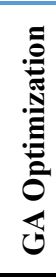 \\
\hline De Nardin [8] & 1986 & & & $\mathrm{x}$ & & $\mathrm{x}$ & & & \\
\hline Pekbey et al. [23] & & & & & $\mathrm{x}$ & & $\mathrm{x}$ & $\mathrm{x}$ & \\
\hline Caldas et al. [13] & 1986 & & & & $\mathrm{x}$ & & $\mathrm{x}$ & & \\
\hline Oliveira [14] & & & & & & $\mathrm{x}$ & & & \\
\hline Dundu $[10]$ & & & & & & $\mathrm{x}$ & & & \\
\hline Gajalakshmi and Helena [11] & & & & & & $\mathrm{x}$ & & & \\
\hline Tao et al. [17] & & & & & $\mathrm{x}$ & $\mathrm{x}$ & & & \\
\hline Papavasileiou et al. [15] & & & $\mathrm{x}$ & & & & & $\mathrm{x}$ & \\
\hline Canales [20] & 2008 & $\mathrm{x}$ & & & & & $\mathrm{x}$ & & \\
\hline Thai et al. [18] & & & & & $\mathrm{x}$ & $\mathrm{x}$ & $\mathrm{x}$ & & \\
\hline Aghdamy et al. [16] & & & & & $\mathrm{x}$ & $\mathrm{x}$ & $\mathrm{x}$ & & \\
\hline Papavasileiou and Charmpis [21] & & & & & & & $\mathrm{x}$ & $\mathrm{x}$ & \\
\hline Papavasileiou and Charmpis [21] & & & & & $\mathrm{x}$ & & $\mathrm{x}$ & $\mathrm{x}$ & \\
\hline Duarte et al. [9] & & & & & & $\mathrm{x}$ & & & \\
\hline Wang et al. [19] & & & & & & $\mathrm{x}$ & & & \\
\hline Wang et al. [19] & & & & & $\mathrm{x}$ & & $\mathrm{x}$ & & \\
\hline Brauns and Skadins [24] & & & & & $\mathrm{x}$ & & $\mathrm{x}$ & $\mathrm{x}$ & \\
\hline Kuranovas et al. [12] & & & $\mathrm{x}$ & $\mathrm{x}$ & & $\mathrm{x}$ & $\mathrm{x}$ & & \\
\hline Lourenção and Alves [22] & 2008 & $\mathrm{x}$ & & & & & $\mathrm{x}$ & $\mathrm{x}$ & \\
\hline PRESENT PAPER & 2008 & $\mathrm{x}$ & $\mathrm{x}$ & $\mathrm{x}$ & & & $\mathrm{x}$ & & $\mathrm{x}$ \\
\hline
\end{tabular}




\section{FORMULATION OF THE OPTIMIZATION PROBLEM}

The design of composite filled columns is based on determining the loads acting on the structure, followed by comparing load values with the pertinent design resistances. As such, the optimization problem is based on finding an optimal solution that minimizes a pre-determined objective or fitness function, which in this case is total cost of the column. The function to be minimized in this research is given by Equation 1 and includes the costs of concrete, steel profile and reinforcement steel bars.

$f_{(\min )}=C_{c} A_{c} L+C_{a} A_{a} L \rho_{a}+C_{s} A_{s} L \rho_{s}$

In Equation $1, C_{c}=$ cost of industrial concrete $\left(\mathrm{R} \$ / \mathrm{m}^{3}\right) ; A_{c}=$ cross-section are of concrete $\left(\mathrm{m}^{2}\right) ; C_{a}=$ cost of the steel profile (not including the type of tubular profile) $(\mathrm{R} \$ / \mathrm{kg}) ; A_{a}=$ cross-sectional area of profiled steel $\left(\mathrm{m}^{2}\right) ; \rho_{a}=$ specific mass of the steel profile $\left(\mathrm{kg} / \mathrm{m}^{3}\right) ; C_{s}=$ cost of longitudinal steel reinforcement $(\mathrm{R} \$ / \mathrm{kg}) ; A_{s}=$ Cross-sectional area of steel reinforcement $\left(\mathrm{m}^{2}\right) ; \rho_{s}=$ specific mass of steel reinforcement $\left(\mathrm{kg} / \mathrm{m}^{3}\right)$; and $L=$ length of the column under analysis $(\mathrm{m})$.

\subsection{Design Variables}

The design variables of the computer program developed for this research are shown in Figure 1, according to crosssection type:
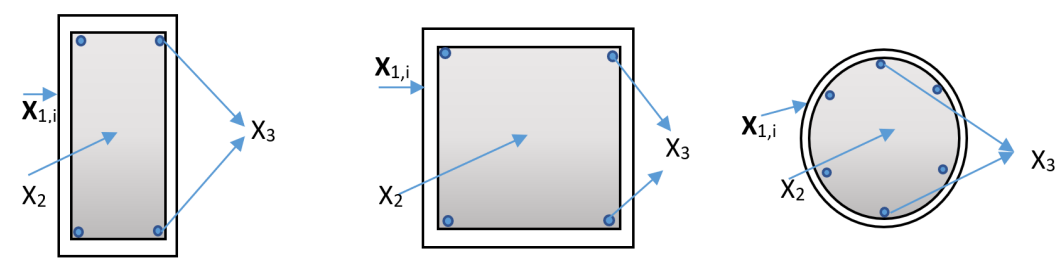

Figure 1. Groups of parameters that define the design variables.

Where:

$\mathbf{x}_{1, i}-$ vector containing the geometric properties of the tubular profile, extracted from commercially available tubular profile catalogues. The definition of each vector element according to cross-section type is given by Table 2 .

Table 2 - Definition of design variables.

\begin{tabular}{cccc}
\hline Variables & $\begin{array}{c}\text { Rectangular } \\
\text { Section }\end{array}$ & Square Section & Circular Section \\
\hline Width & $\mathrm{x}_{1,1}=\mathrm{b}$ & $\mathrm{x}_{1,1}=\mathrm{b}=\mathrm{h}$ & - \\
\hline Height & $\mathrm{x}_{1,2}=\mathrm{h}$ & $\mathrm{x}_{1,1}=\mathrm{b}=\mathrm{h}$ & - \\
\hline Diameter & - & $\mathrm{x}_{1}=\mathrm{d}$ & $\mathrm{x}_{1,2}=\mathrm{t}$ \\
\hline Thickness & $\mathrm{x}_{1,3}=\mathrm{t}$ & $\mathrm{x}_{1,2}=\mathrm{t}$ & $\mathrm{x}_{1,3}=\mathrm{A}_{\mathrm{a}}$ \\
\hline Area of Steel & $\mathrm{x}_{1,4}=\mathrm{A}_{\mathrm{a}}$ & $\mathrm{x}_{1,3}=\mathrm{A}_{\mathrm{a}}$ & $\mathrm{x}_{1,4}=\mathrm{I}_{\mathrm{ax}}$ \\
\hline Moment of inertia $-x$ axis & $\mathrm{x}_{1,5}=\mathrm{I}_{\mathrm{ax}}$ & $\mathrm{x}_{1,4}=\mathrm{I}_{\mathrm{ax}}$ & $\mathrm{x}_{1,5}=\mathrm{I}_{\mathrm{ay}}$ \\
\hline Moment of inertia $-y$ axis & $\mathrm{x}_{1,6}=\mathrm{I}_{\mathrm{ay}}$ & $\mathrm{x}_{1,5}=\mathrm{I}_{\mathrm{ay}}$ & $\mathrm{x}_{1,6}=\mathrm{Z}_{\mathrm{ax}}$ \\
\hline Plastic section modulus $-\mathrm{x}$ axis & $\mathrm{x}_{1,7}=\mathrm{Z}_{\mathrm{ax}}$ & $\mathrm{x}_{1,6}=\mathrm{Z}_{\mathrm{ax}}$ & $\mathrm{x}_{1,7}=\mathrm{Z}_{\mathrm{ay}}$ \\
\hline Plastic section modulus $-\mathrm{y}$ axis & $\mathrm{x}_{1,8}=\mathrm{Z}_{\mathrm{ay}}$ & $\mathrm{x}_{1,7}=\mathrm{Z}_{\mathrm{ay}}$ & \\
\hline
\end{tabular}

$\mathrm{x}_{2}$ - represents the characteristic strength of concrete, that may vary throughout the optimization process; $\mathrm{x}_{3}-$ total cross-section area of longitudinal reinforcement taken as a discrete variable as a function of the number of bars, if applicable.

\subsection{Constraint Functions}

The constraints of the problem are taken from the three standards. Interaction curves $(N \times M)$ for each standard are given in Figure 2. 


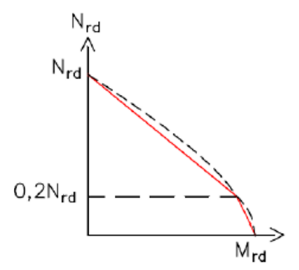

(a)

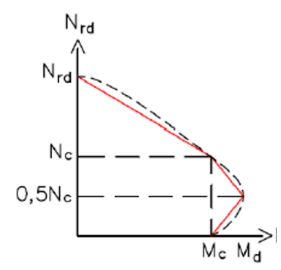

(b)

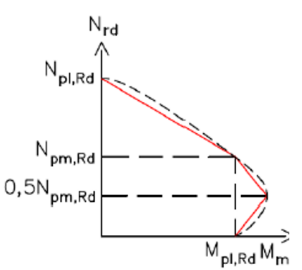

(c)

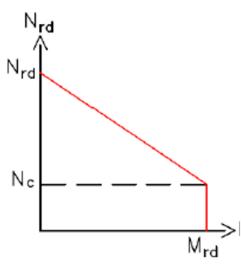

(d)

Figure 2 - Interaction diagrams for bending moment vs. axial force -(a) Design model I ABNT NBR 8800 [1]; (b) Design model II ABNT NBR 8800 [1]; (c) ABNT NBR 16239 [2]; (d) EN 1994-1-1 [3].

\subsubsection{ABNT NBR 8800 [1] and ABNT NBR 16239 [2]}

- Resistant design forces must be larger than applied design loads

$N_{R d} \geq N_{S d}$

$M_{x, R d} \geq M_{x, S d}$

$M_{y, R d} \geq M_{y, S d}$

Where: $N_{d}, M_{x, d}, M_{y, d}$ are the design resistance to axial force and design resistance to bending moment about the x and y axes, respectively, with subscript $R$ indicating resistant, and subscript $S$ indicating applied load.

- Resistance to combined loads must be higher than applied combined loads

o Design model I (ABNT NBR 8800 [1]):

$\frac{N_{S d}}{N_{R d}} \geq 0,2 \frac{N_{S d}}{N_{R d}}+\frac{8}{9}\left(\frac{M_{x, S d}}{M_{x, R d}}+\frac{M_{y, S d}}{M_{y, R d}}\right) \leq 1,0$

$\frac{N_{S d}}{N_{R d}}<0,2 \frac{N_{S d}}{2 N_{R d}}+\left(\frac{M_{x, S d}}{M_{x, R d}}+\frac{M_{y, S d}}{M_{y, R d}}\right) \leq 1,0$

o Design model II (ABNT NBR 8800 [1]):

$\frac{M_{x, t o t, S d}}{\mu_{x} M_{c, x}}+\frac{M_{y, t o t, S d}}{\mu_{y} M_{c, y}} \leq 1,0$

o Design model from ABNT NBR 16239 [2]:

$N_{S d} \leq N_{c} \frac{M_{x, S d}}{M_{x, R d}}+\frac{M_{y, S d}}{M_{y, R d}} \leq 1,0$

$N_{S d}>N_{c} \frac{N_{S d}-N_{c}}{N_{R d}-N_{c}}+\frac{M_{x, S d}}{M_{x, R d}}+\frac{M_{y, S d}}{M_{y, R d}} \leq 1,0$

The design resistance to axial force is given by: 
$N_{R d}=\chi N_{p l, R d}$

Where $\chi$ is the reduction factor and $N_{p l, R d}$ is the design plastic resistance to normal forces of the gross cross-section, given by Equation 11 .

$$
N_{p l, R d}=A_{a} f_{y d}+\alpha A_{c} f_{c d}+A_{s} f_{s d}
$$

Where $\alpha=0,95$ for circular sections and $\alpha=0,85$ for other section types.

The reduction factor $\chi$ is determined by Equations 12 and 13, according to ABNT NBR 8800 [1]. However, ABNT NBR 16239 [2] recommends the use of Equation 14.

$\lambda_{0, m} \leq 1,5 \quad \chi=0,658^{\lambda_{0, m}^{2}}$

$\lambda_{0, m}>1,5 \quad \chi=\frac{0,877}{\lambda_{0, m}{ }^{2}}$

$\chi=\frac{1}{\left(1+\lambda_{0, m} 4,48\right)^{\frac{1}{2,24}}}$

Where:

$\lambda_{0, m}=\sqrt{\frac{N_{p l, R}}{N_{e}}}$

Where $N_{p l, R}$ is the value of $N_{p l, R d}$ with resistance factors $\gamma_{a}, \gamma_{c}$ and $\gamma_{s}$ taken as 1,0 and $N_{e}$ is the elastic critical buckling load

The modulus of elasticity of concrete is defined according to recommendations from ABNT NBR 6118 [32], since it is a more recent standard.

$E_{c}=\propto_{i} E_{c i}\left\{\begin{array}{c}\propto_{i}=0,8+0,2 \frac{f_{c k}}{80} \leq 1.0 \\ E_{c i}=\left\{\begin{array}{c}\propto_{e} 5600 \sqrt{f_{c k}} 20 \mathrm{MPa} \leq f_{c k} \leq 50 \mathrm{MPa} \\ \propto_{e} 21500 \sqrt[3]{f_{c k}+1,25} \quad 50 \mathrm{MPa}<f_{c k} \leq 90 \mathrm{MPa}\end{array}\right.\end{array}\right.$

Where: $\alpha_{e}=1,2$ if basalt and diabase are used as aggregates, 1,0 for granite and gneiss, 0,9 for granite and 0,7 for sandstone.

- Applicability limits for tubular sections:

Rectangular Square Circular

$\frac{x_{1,1}}{x_{1,3}} \leq 2,26 \sqrt{\frac{E_{a}}{f_{y}}} e$ 


$$
\frac{x_{1,2}}{x_{1,3}} \leq 2,26 \sqrt{\frac{E_{a}}{f_{y}}} \frac{x_{1,1}}{x_{1,2}} \leq 2,26 \sqrt{\frac{E_{a}}{f_{y}}} \quad \frac{x_{1,1}}{x_{1,2}} \leq 0,15 \frac{E_{a}}{f_{y}}
$$

Where: $E_{a}$ is the modulus of elasticity of steel and $f_{y}$ is the yield strength of steel.

- Steel contribution factor of the composite section

$$
0,2<\delta=\frac{A_{a} f_{y d}}{N_{R d}}<0,9
$$

Where: $A_{a}$ cross-sectional area of the structural steel profile; $f_{y d}$ is the design yield strength of the profiled steel.

If longitudinal reinforcement is used:

- Number of bars $\left(n_{B}\right)$ :

o Rectangular and square sections

$n_{B} \geq 4$

o Circular sections

$n_{B} \geq 6$

- Minimum and maximum area of longitudinal reinforcement

$$
\max \left(0,004 A_{c} ; 0,15 \frac{N_{S d}}{f_{S d}}\right) \leq A_{S} \leq 0,04 A_{C}
$$

Where: $A_{c}$ is cross-sectional area of concrete; $A_{s}$ is the cross-sectional area of longitudinal reinforcement; $f_{y d}$ is the design yield strength of steel for the reinforcement bars.

- Maximum and minimum bar spacing in each direction for:

o Rectangular sections

$$
s_{x}=\frac{x_{1,1}-2 x_{1,3}-2 d^{\prime}-n_{B x} \varnothing_{b}}{n_{B x}-1}
$$

$\max \left(2 \mathrm{~cm} ; \varnothing_{b}\right) \leq s_{x} \leq \min \left[40 \mathrm{~cm} ; 2 \min \left(x_{1,1}-2 x_{1,3} ; x_{1,2}-2 x_{1,3}\right)\right]$

$s_{y}=\frac{x_{1,2}-2 x_{1,3}-2 d^{\prime}-n_{B y} \varnothing_{b}}{n_{B y}-1}$

$\max \left(2 \mathrm{~cm} ; \varnothing_{b}\right) \leq s_{y} \leq \min \left[40 \mathrm{~cm} ; 2 \min \left(x_{1,1}-2 x_{1,3} ; x_{1,2}-2 x_{1,3}\right)\right]$

o Square sections 
$s_{x}=\frac{x_{1,1}-2 x_{1,2}-2 d^{\prime}-n_{B x} \varnothing_{b}}{n_{B x}-1}$

$\max \left(2 \mathrm{~cm} ; \varnothing_{b}\right) \leq s_{x} \leq \min \left[40 \mathrm{~cm} ; 2\left(x_{1,1}-2 x_{1,2}\right)\right]$

$s_{y}=\frac{x_{1,1}-2 x_{1,2}-2 d^{\prime}-n_{B y} \varnothing_{b}}{n_{B y}-1}$

$\max \left(2 \mathrm{~cm} ; \varnothing_{b}\right) \leq s_{y} \leq \min \left[40 \mathrm{~cm} ; 2\left(x_{1,1}-2 x_{1,2}\right)\right]$

o Circular sections

$s=\frac{2 \pi\left(\frac{x_{1,1}}{2}-x_{1,2}-d^{\prime}-\frac{\varnothing_{b}}{2}\right)-n_{B} \varnothing_{b}}{n_{B}}$

$\max \left(2 \mathrm{~cm} ; \varnothing_{b}\right) \leq s \leq 40 \mathrm{~cm}$

\subsection{EN 1994-1-1 [3]}

Constraints for this standard are identical to those detailed in section 3.2.1, with the exception of the following:

- Resistance to combined loads must by higher than applied combined loads

$\frac{M_{x, E d}}{\mu_{x} M_{p l, x, R d}} \leq \alpha_{M}$

$\frac{M_{y, E d}}{\mu_{y} M_{p l, y, R d}} \leq \alpha_{M}$

$\frac{M_{x, E d}}{\mu_{x} M_{p l, x, R d}}+\frac{M_{y, E d}}{\mu_{y} M_{p l, y, R d}} \leq 1,0$

Where $\alpha_{\mathrm{m}}$ is taken as 0,9 for steels in which $235 \mathrm{MPa} \leq f_{y} \leq 355 \mathrm{MPa}$ and 0,8 if $420 \mathrm{MPa} \leq f_{y} \leq 460 \mathrm{MPa}$.

Thus, the design plastic resistance to normal forces of the gross-section for square and rectangular sections are determined by Equation 35. EN 1994-1-1 [3] also accounts for increases in concrete strength induced by concrete confinement effects in circular hollow sections, provided $\lambda<0,5$ and the ratio $e / D<0,1$, where $e$ is given by $M_{S d} / N_{S d}$ and $D$ is the diameter of the steel profile. Should these conditions be satisfied, the design resistance to normal forces considering concrete confinement for circular sections is given by Equation 40 .

$N_{p l, R d}=A_{a} f_{y d}+\alpha A_{c} f_{c d}+A_{s} f_{s d}$

Where $\alpha=1,0$ for concrete-filled tubular sections and 0,85 for other section types. The normal resistant effort is given by: 
$N_{R d}=\chi N_{p l, R d}$

Where: $\chi$ is a resistance reduction factor determined in accordance with EN 1994-1-1 [3].

$\chi=\frac{1}{\Phi+\sqrt{\Phi^{2}-\lambda^{2}}}$

and,

$\Phi=0,5\left[1+\alpha(\lambda-0,2)+\lambda^{2}\right]$

In which,

$\lambda=\sqrt{\frac{N_{p l, R k}}{N_{c r}}}$

Where $N_{p l, R k}$ is equal to $N_{p l, R d}$ if resistant factors $\gamma_{a}, \gamma_{c}$ e $\gamma_{s}$ are taken as 1,0.

For circular sections, the plastic resistance to normal forces for the gross-section is given by:

$N_{p l, R d}=\eta_{a} A_{a} f_{y d}+A_{c} f_{c d}\left(1+\eta_{c} \frac{t}{d} \frac{f_{y k}}{f_{c k}}\right)+A_{s} f_{s d}$

Where:

$\eta_{c}=\left\{\begin{array}{c}\eta_{c 0}\left(1+10 \frac{e}{D}\right) \text { for } e / D \leq 0,1 \\ \text { for } e / D>0,1 \\ \eta_{c 0}=4,9-18,5 \lambda+17 \lambda^{2}\end{array}\right.$

$\eta_{a}=\left\{\begin{array}{c}\left.\eta_{a 0}+\left(1-\eta_{a 0}\right)\left(10 \frac{e}{D}\right)\right) \text { for } e / D \leq 0,1 \\ \text { for } e / D>0,1 \\ \eta_{a 0}=0,25(3+2 \lambda)\end{array}\right.$

- Applicability limit for tubular sections:

Rectangular Square Circular

$\frac{x_{1,1}}{x_{1,3}} \leq 52 \sqrt{\frac{235}{f_{y}}} e$ 
$\frac{x_{1,2}}{x_{1,3}} \leq 52 \sqrt{\frac{235}{f_{y}}} \quad \frac{x_{1,1}}{x_{1,2}} \leq 52 \sqrt{\frac{235}{f_{y}}} \quad \frac{x_{1,1}}{x_{1,2}} \leq 90 \sqrt{\frac{235}{f_{y}}}$

If longitudinal reinforcement is used:

- Number of bars $\left(n_{B}\right)$ :

o Rectangular and Square sections

$n_{B} \geq 4$

o Circular sections

$n_{B} \geq 4$

- Minimum and maximum area of longitudinal reinforcement

$\max \left(0,003 A_{c} ; 0,10 \frac{N_{S d}}{f_{S d}}\right) \leq A_{S} \leq 0,06 A_{c}$

- Minimum and maximum bar spacing in each direction for:

o Rectangular Sections

$s_{x}=\frac{x_{1,1}-2 x_{1,3}-2 d^{\prime}-n_{B x} \varnothing_{b}}{n_{B x}-1}$

$\max \left(2 \mathrm{~cm} ; \varnothing_{b}\right) \leq s_{x} \leq 40 \mathrm{~cm}$

$s_{y}=\frac{x_{1,2}-2 x_{1,3}-2 d^{\prime}-n_{B y} \varnothing_{b}}{n_{B y}-1}$

$\max \left(2 \mathrm{~cm} ; \varnothing_{b}\right) \leq s_{y} \leq 40 \mathrm{~cm}$

o Square Sections

$s_{x}=\frac{x_{1,1}-2 x_{1,2}-2 d^{\prime}-n_{B x} \varnothing_{b}}{n_{B x}-1}$

$\max \left(2 \mathrm{~cm} ; \varnothing_{b}\right) \leq s_{x} \leq 40 \mathrm{~cm}$

$s_{y}=\frac{x_{1,1}-2 x_{1,2}-2 d^{\prime}-n_{B y} \varnothing_{b}}{n_{B y}-1}$

$\max \left(2 \mathrm{~cm} ; \varnothing_{b}\right) \leq s_{y} \leq 40 \mathrm{~cm}$ 
o Circular Sections

$s=\frac{2 \pi\left(\frac{x_{1,1}}{2}-x_{1,2}-d^{\prime}-\frac{\varnothing_{b}}{2}\right)-n_{B} \varnothing_{b}}{n_{B}}$

$\max \left(2 \mathrm{~cm} ; \varnothing_{b}\right) \leq s \leq 40 \mathrm{~cm}$

\section{RESULTS AND DISCUSSION}

To illustrate the advantages of implementing the formulation described herein, three case studies are presented, shown in Figure 3. All examples include the three types of cross-section, designed using the three standards previously mentioned, in addition to considering columns with and without longitudinal reinforcement. On the first example, columns are subjected to pure compression; the second example includes bending about one principal axis in addition to compression; and the third considers the level of compression along with bending about both principal axes.

The costs of steel (R $\$ 5,01 / \mathrm{kg}$ ) and concrete were extracted from the SINAPI table, composed by Caixa Econômica Federal in March of 2020 [33]. Prices from the table already include labor costs attributed to mixing and pumping the concrete. The modulus of elasticity of concrete is defined considering concretes using granite/gneiss as aggregates. The cost per kilogram of structural profile was obtained from consulting the company Vallourec [34], which informed a price of R $\$ 4,50 / \mathrm{kg}$ for circular profiles and R $\$ 5,50 / \mathrm{kg}$ for rectangular profiles. Furthermore, since the examples consider discrete variables, compressive strengths of concrete range from $20 \mathrm{MPa}$ to $90 \mathrm{MPa}$ in $5 \mathrm{MPa}$ increments. The diameter of steel reinforcement bars considered range from $8 \mathrm{~mm}$ to $16 \mathrm{~mm}$, respecting the constraint functions established for minimum and maximum reinforcement area.

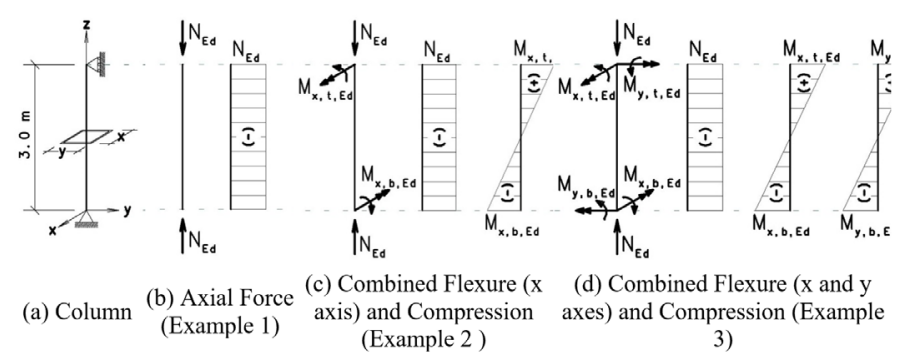

Figure 3 - Sequence of the four load cases analyzed and the respective axial forces and bending moments applied

It is important to note that reference prices obtained are applicable to the southeastern region of Brazil and may differ from other regions of the country. Table 3 summarizes the cost for each material and the source from which they were obtained. Figure $4 \mathrm{a}$ presents the data entry screen of the program and Figure $4 \mathrm{~b}$ shows the result output.

Table 3. Cost of materials

\begin{tabular}{|c|c|c|c|c|}
\hline $\begin{array}{l}\text { Concrete } \\
\mathbf{f}_{\mathrm{ck}}(\mathbf{M P a}) \\
\end{array}$ & $\begin{array}{c}\text { Average Price } \\
\left(\mathbf{R} \$ / \mathbf{m}^{3}\right)\end{array}$ & Concrete $f_{\text {ck }}(\mathbf{M P a})$ & $\begin{array}{c}\text { Average Price } \\
\left(\mathbf{R} \$ / \mathbf{m}^{3}\right)\end{array}$ & Source \\
\hline 20 & 295,00 & 55 & 520,13 & \multirow{9}{*}{$\begin{array}{c}\text { Table SINAPI - Price of materials (Caixa Econômica } \\
\text { Federal). Reference month: February/2020. Locality: } \\
\text { Vitória/ES }\end{array}$} \\
\hline 25 & 307,42 & 60 & 584,82 & \\
\hline 30 & 317,77 & 65 & 640,46 & \\
\hline 35 & 329,15 & 70 & 696,09 & \\
\hline 40 & 341,57 & 75 & 751,73 & \\
\hline 45 & 384,01 & 80 & 807,36 & \\
\hline \multirow[t]{2}{*}{50} & 455,43 & 85 & 891,53 & \\
\hline & & 90 & 952,81 & \\
\hline Steel CA50 & 5,01 & & & \\
\hline VMB350 & 4,50 & & & \multirow{2}{*}{ Vallourec. Reference: March/2020 } \\
\hline VMB350 & 5,50 & & & \\
\hline
\end{tabular}


The Transportation cost of structural profiles usually represent $1 \%$ to $3 \%$ of the total cost of a steel structural systems. This is comparable to the costs of the structural design (1\% to $3 \%)$ detailing $(2 \%$ a $5 \%)$ [35] and assembly $(20 \%$ a $30 \%)$ in relation to the cost of the entire structure [36]. Since only isolated structural elements are analyzed here, these values can later be proportionally added to all results.

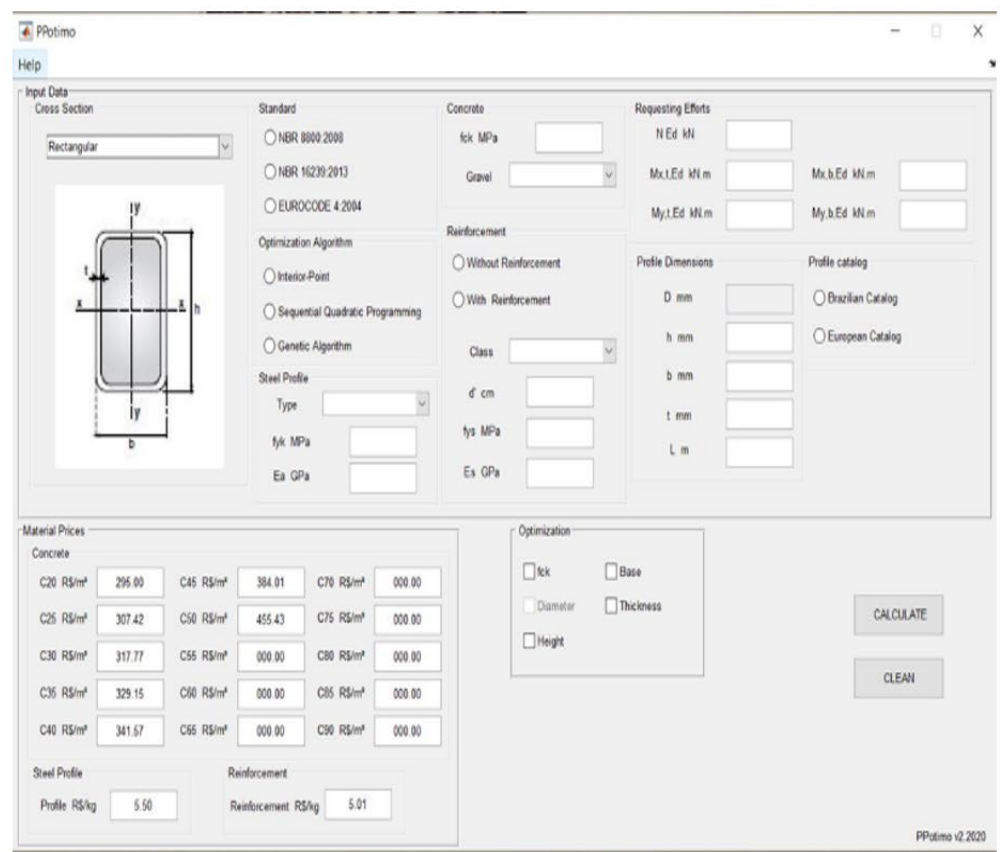

(a)

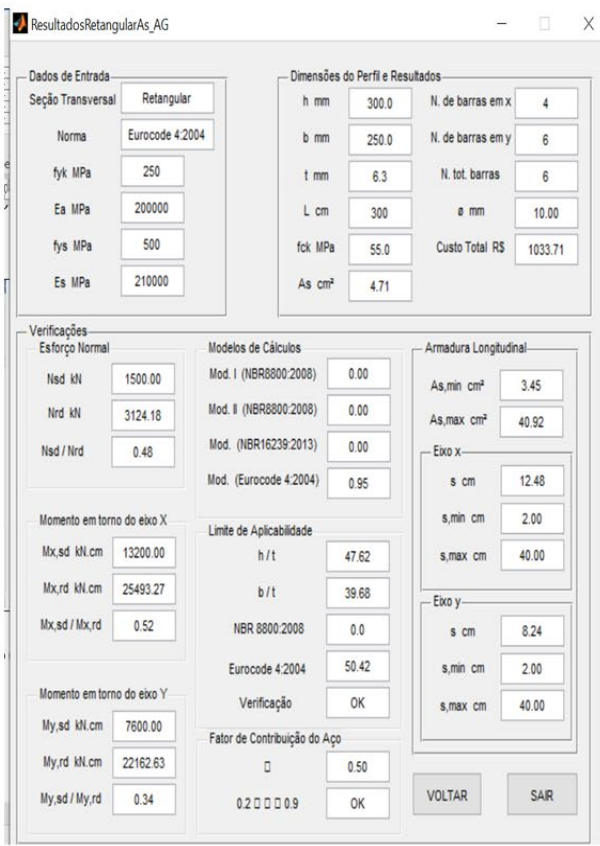

(b)

Figure 4. (a) Input screen of the developed software; (b) Output screen.

\subsection{Example 1 - Design optimization of columns subjected to pure compression}

In this example columns were subjected to an axial force $\left(N_{S d}\right)$ of $1000 \mathrm{kN}$. The initial solution is a square column with cross-section dimensions b:h of $150 \mathrm{~mm}$, tube thickness of $12,5 \mathrm{~mm}$, compressive strength of concrete $\left(f_{c k}\right)$ of 30 $\mathrm{MPa}$, yield strength of steel $\left(f_{y k}\right)$ equal to $250 \mathrm{MPa}$ and a length of $3 \mathrm{~m}$. All three sections were analyzed and results are shown in Table 4. This example was validated using data from the software PilarMisto 3.04.11 provided by Lourenção and Alves [22] (Caldas et al. [37]) using the standard ABNT NBR 8800 [1]. The active constraint (AC) for all columns in this example was the resistance to normal forces.

As shown in Table 4, in $72 \%$ of the solutions, the optimum design features concrete with $f_{c k}$ larger than $50 \mathrm{MPa}$. Even though these grades of concrete are of higher cost, if the ratio cost/strength is considered, the increased expenditure is not a decisive factor. Table 4 also shows that results obtained with GA are lesser in value than the initial solution. Comparing the solution presented by Lourenção and Alves [22], using continuous variables, with the best solution obtained via GA when using ABNT NBR 16239: 2013, it is observed that the final cost of the column is $11.52 \%$ more expensive when compared to the square section and $4.6 \%$ cheaper when compared to the circular section. However, the value of $f_{c k}$ for the circular sections was the same obtained by Lourenção e Alves[22].

Figure 5 presents graphs for the analyses performed, based on the results obtained. Figure $5 \mathrm{a}$ shows the ratio between cost and applied load for different cross-section geometries. For this example, ABNT NBR 16239 [2] produced the best solutions when applied to the design of circular columns without longitudinal reinforcement, followed by EN 1994-1-1 [3]. The least favorable solution is obtained from the design procedure provided by ABNT NBR 8800 [1] considering longitudinal reinforcement. 
Table 4 - Optimization Results Example 1: $\mathrm{L}=3 \mathrm{~m} ; \mathrm{N}_{\mathrm{Sd}}=1000 \mathrm{kN}$

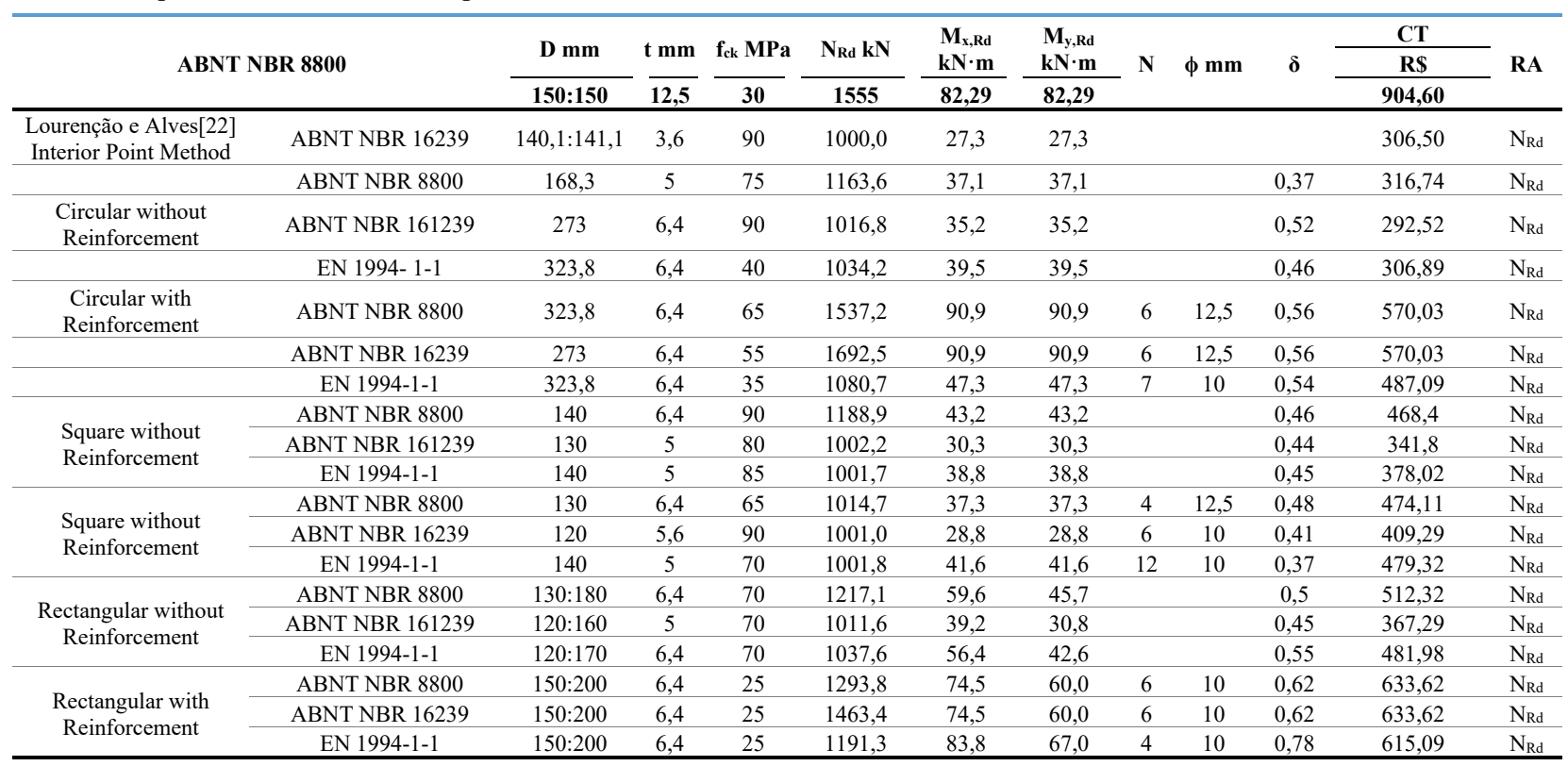

Figure $5 \mathrm{~b}$ presents a comparative analysis between solutions obtained with GA and the initial solution, in addition to comparing solutions for each geometry and the overall optimal solution for this case. All solutions obtained with GA were significantly smaller in magnitude than the initial solution, with the least favorable solution obtained with ABNT NBR 8800 [1] showing a reduction of $40 \%$ in relation to the original solution. If solutions are compared with each other, it is observed that the optimum case corresponds to the circular column designed using ABNT NBR 16239 [2]. The least favorable solution corresponds to the rectangular column. The graph also indicates that results obtained with EN 1994-1-1 [3] are very similar to those of ABNT NBR 16239 [2].

Alternatively, Figure $5 \mathrm{c}$ presents a composition of the cost of the composite filled column, and Figure $5 \mathrm{~d}$ shows the contribution of each material to the resistance to normal forces $\left(N_{R d}\right)$ for different geometries. As observed in Figure $5 \mathrm{c}$, the material with the most impact on the cost of the column is the structural profile, accounting for at least $80 \%$ of the price. However, the material that most contributes to the resistant strength of the column is the concrete with additional longitudinal reinforcement (Figure 5d), corroborating results obtained via GA.

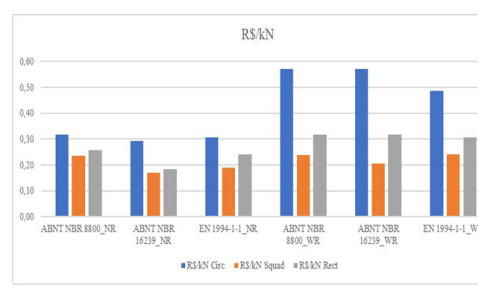

(a)

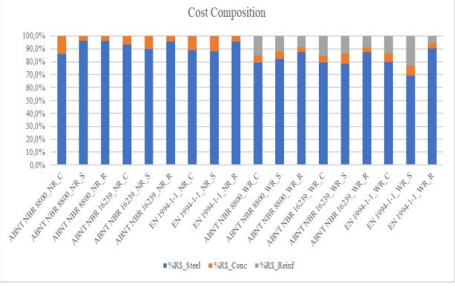

(c)

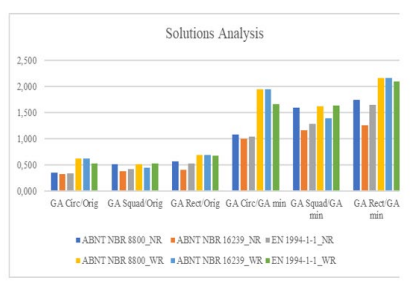

(b)

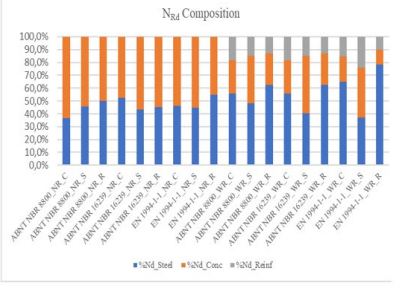

(d)

Figure 5 - (a) Ratio R $\$ / N_{S d}$; (b) Ratio AG/Original Solution; (c) Cost composition of composite filled columns (d) Composition of the resistance to normal forces of the composite filled column. 


\subsection{Example 2 - Design Optimization of Columns Subjected to Combined Axial force and Bending Moment}

Columns in this example are subjected to a compressive force $\left(N_{S d}\right)$ of $1500 \mathrm{kN}$ in addition to end moments $\left(M_{x, S d}\right)$ of magnitude $132 \mathrm{kN} \cdot \mathrm{m}$ about the $\mathrm{x}$ axis. The initial solution was proposed by Canales [20] using design prescriptions from ABNT NBR 16239 [2], verified by Lourenção and Alves [22] for a circular profile with a diameter of 323,8 mm, wall thickness of $10,3 \mathrm{~mm}$, and a length of $4 \mathrm{~m}, f_{c k}$ of $30 \mathrm{MPa}$ and $f_{y k}$ of $250 \mathrm{MPa}$. Table 5 presents the results for this example.

Table 5 - Optimization Results Example 2: $\mathrm{L}=4 \mathrm{~m} ; \mathrm{N}_{\mathrm{Sd}}=2000 \mathrm{kN} ; \mathrm{M}_{\mathrm{x}, \mathrm{Sd}}=132 \mathrm{kN} \cdot \mathrm{m}$

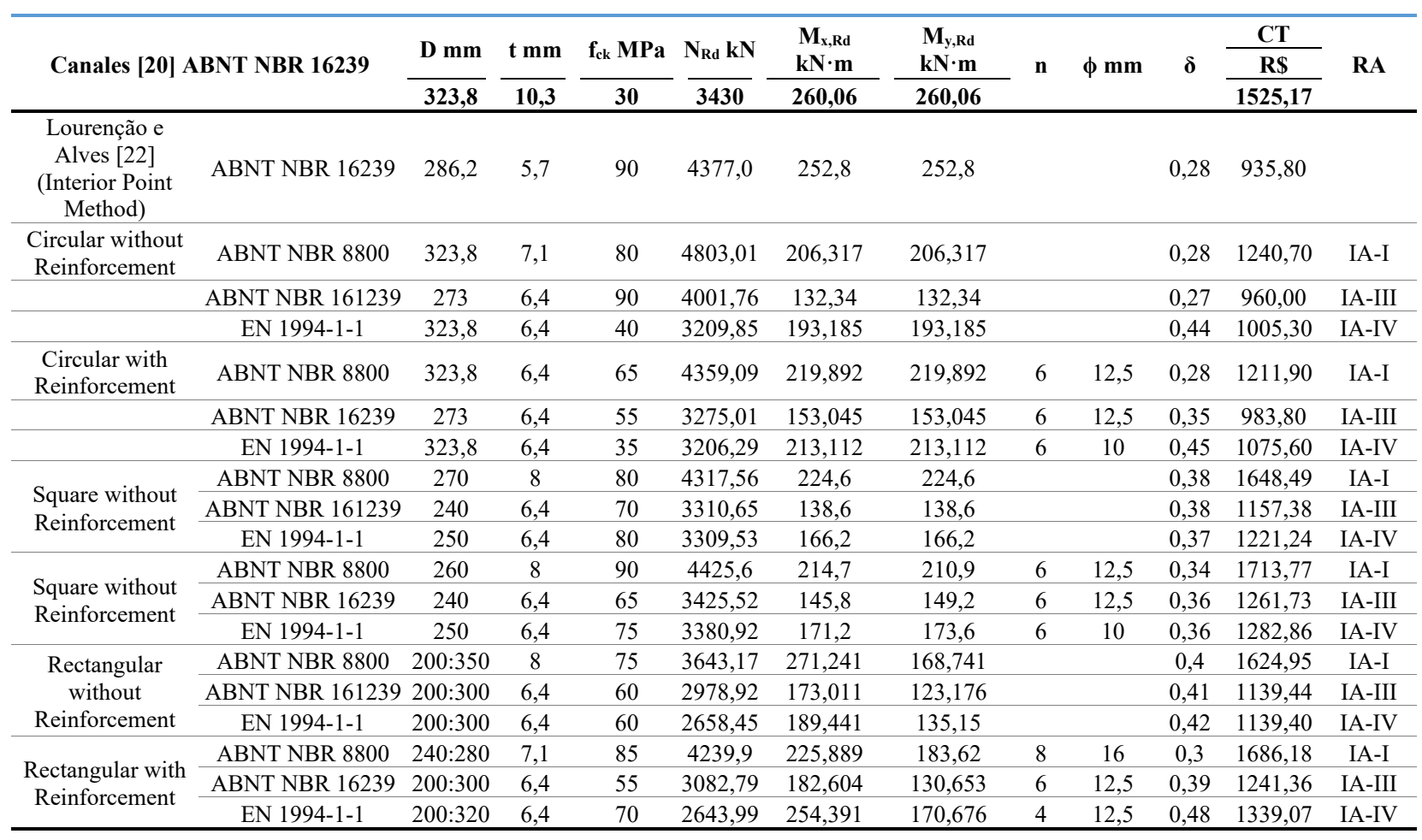

Table 5 shows that in $89 \%$ of cases, the optimum solution is obtained for concretes with $f_{c k}$ larger than $50 \mathrm{MPa}$, with this being the case in $100 \%$ of columns featuring square and rectangular sections. The active constraint was the interaction curve for each standard presented in Figure 2, for ABNT NBR 8800 [1], this was the case for the design model I (Figure 2a). Furthermore, ABNT NBR 8800 [1] presents the most conservative results for square and rectangular sections with and without longitudinal reinforcement, with the GA solution presenting a higher cost than the solution found by Canales [20], in which the original column features a circular cross-section. Remaining approaches yielded results smaller than those presented by the author. Among the methodologies tested, once more the optimum solution corresponds to the circular column designed with provisions from ABNT NBR 16239[2], which presented results like those obtained with EN 1994-1-1[1]. Alternatively, the least favorable solutions correspond to the square columns.

Comparing the solution presented by Lourenção and Alves [22], using continuous variables, with the best solution obtained via GA when using ABNT NBR 16239 [2], it is observed that the final cost of the column is 5\% more expensive. However, both solutions indicate the same optimal value of $f_{c k}$

In similar fashion to the previous example, Figure 6 presents an analysis of the solutions and the parameters that influenced them the most.

Figure 6a shows the ratio between cost of the columns and design applied load. The graph shows that ABNT NBR 16239 [2] presents the best solutions for all sections and for all columns without longitudinal steel reinforcement. ABNT NBR 8800 [1] yields the most conservative results when compared to other standards. The graph in Figure 6b shows that results obtained with EN1994-1 [3] are slightly larger, albeit close to ABNT NBR 16239 [2].

The graphs in Figures 6c and Figure 6d present the cost composition of the columns and the material contribution to the resistance to normal forces $\left(N_{R d}\right)$, respectively, as a function of materials. Steel is observed to bear the highest impact on the cost of columns, with an average contribution of $83 \%$. 
Concrete and steel reinforcement present the largest contributions to column strength, showing an average of $63 \%$, while the structural profile correspond, in average, to $37 \%$ of the total resistance. These results explain the reason why optimum solutions usually feature concrete with higher values of compressive strength $f_{c k}$.

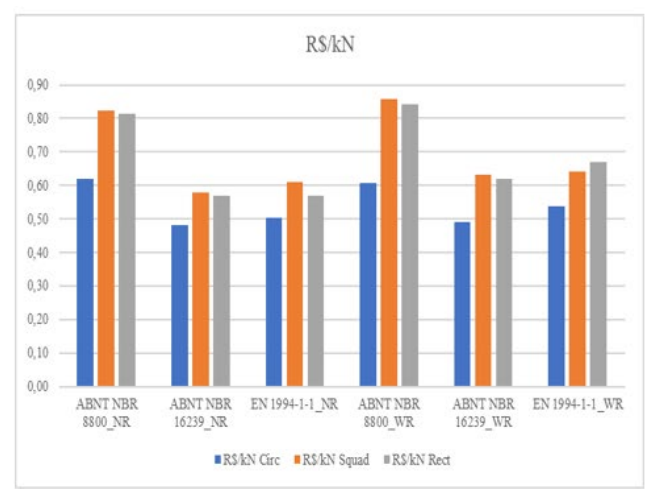

(a)

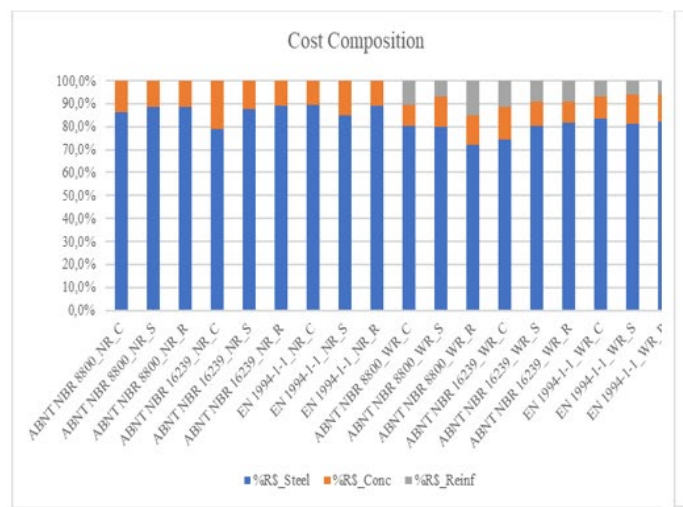

(c)

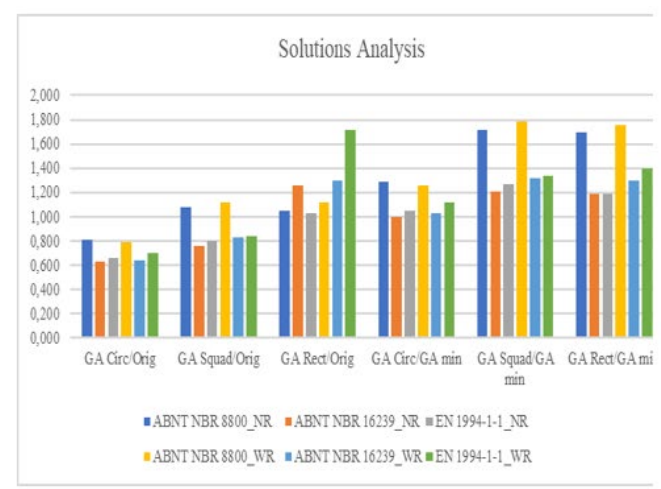

(b)

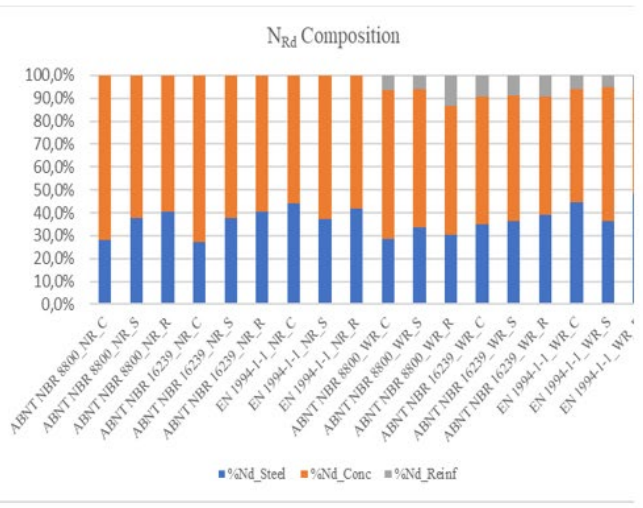

(d)

Figure 6 - (a) Ratio R $\$ / N_{S d}$; (b) Ratio AG/Original Solution; (c) Cost composition of composite filled columns (d) Composition of the resistance to normal forces of the composite filled column.

\subsection{Example 3 - Design optimization of columns subjected to combined axial force and bending about the $x$ and $\mathbf{y}$ axes}

In addition to the $1500 \mathrm{kN}$ compressive force $\left(N_{S d}\right)$, and the $132 \mathrm{kN} \cdot \mathrm{m}$ bending moment about the $\mathrm{x}$ axis $\left(M_{x, S d}\right)$, in this example columns are also subjected to a bending moment of $76 \mathrm{kN} \cdot \mathrm{m}$ in the $\mathrm{y}$ direction $\left(M_{y, S d}\right)$ . The initial solution corresponds to a column with a width of $180 \mathrm{~mm}$, height of $300 \mathrm{~mm}$, wall thickness equal to $12,5 \mathrm{~mm}$, and a length of $3 \mathrm{~m}, f_{c k}$ of $40 \mathrm{MPa}$ and $f_{y k}$ of $250 \mathrm{MPa}$. The solution for this column was obtained with the software PilarMisto 3.04.11 [37] using ABNT NBR 8800 [1] as a basis for design, and verified by Lourenção and Alves [22].

Table 6 presents the optimized results for this example, which show that the active constraint (AC) that governs this example corresponds once more to the interaction curves previously shown. It is observed that $56 \%$ of the solutions feature concrete with $f_{c k}$ larger than $50 \mathrm{MPa}$.

The analysis of results shows that all solutions obtained via GA, with the exception of the solution obtained with ABNT NBR 8800 [1], performed better when compared to the solutions found by Lourenção and Alves [22]. This result was expected, considering that the solutions obtained for circular and square sections are better than solutions obtained for rectangular sections, as presented in the previous examples. 
Table 6 - Optimization Results: $\mathrm{L}=3 \mathrm{~m} ; \mathrm{N}_{\mathrm{Sd}}=1500 \mathrm{kN} ; \mathrm{M}_{\mathrm{x}, \mathrm{Sd}}=132 \mathrm{kN} \cdot \mathrm{m} ; \mathrm{M}_{\mathrm{y}, \mathrm{Sd}}=76 \mathrm{kN} \cdot \mathrm{m}$

\begin{tabular}{|c|c|c|c|c|c|c|c|c|c|c|c|c|}
\hline \multirow{2}{*}{\multicolumn{2}{|c|}{$\begin{array}{c}\text { Original Solution- Rectangular ABNT } \\
\text { NBR 8800:2008 }\end{array}$}} & \multirow{2}{*}{$\frac{\mathrm{D} \mathbf{~ m m}}{180: 300}$} & \multirow{2}{*}{$\frac{\mathrm{t} \mathrm{mm}}{12,5}$} & \multirow{2}{*}{$\begin{array}{c}\begin{array}{c}\mathbf{f}_{\text {ck }} \\
\text { MPa }\end{array} \\
\mathbf{4 0} \\
\end{array}$} & \multirow{2}{*}{$\begin{array}{c}\mathbf{N}_{\text {Rd }} \mathbf{k N} \\
3890 \\
\end{array}$} & \multirow{2}{*}{$\begin{array}{l}\begin{array}{l}M_{x, R d} \\
\mathrm{kN} \cdot \mathrm{m}\end{array} \\
\mathbf{4 0 5 , 7 8} \\
\end{array}$} & \multirow{2}{*}{$\frac{\mathrm{M}_{\mathbf{y}, \mathbf{R d}} \mathbf{k N} \cdot \mathbf{m}}{227,01}$} & \multirow[t]{2}{*}{$\mathbf{n}$} & \multirow[t]{2}{*}{$\phi \mathbf{m m}$} & \multirow[t]{2}{*}{ D } & \multirow{2}{*}{$\begin{array}{c}\text { CT } \\
\text { R\$ } \\
1.494,20\end{array}$} & \multirow[t]{2}{*}{ RA } \\
\hline & & & & & & & & & & & & \\
\hline $\begin{array}{l}\text { Lourenção e Alves } \\
\text { [22] (Interior } \\
\text { Point Method }\end{array}$ & ABNT NBR 8800 & 200:400 & 7,9 & 90 & 5098,0 & 341,6 & 186,5 & & & & 1404,60 & IA-I \\
\hline \multirow[t]{3}{*}{$\begin{array}{l}\text { Circular without } \\
\text { Reinforcement }\end{array}$} & ABNT NBR 8800 & 355,6 & 8 & 55 & 5034,71 & 270,0 & 270,0 & & & 0,37 & 1067,60 & IA-I \\
\hline & ABNT NBR 161239 & 323,8 & 8 & 30 & 3303,19 & 209,6 & 209,6 & & & 0,54 & 912,40 & IA-III \\
\hline & EN 1994-1-1 & 323,8 & 6,4 & 45 & 3614,66 & 195,2 & 195,2 & & & 0,41 & 763,60 & IA-IV \\
\hline \multirow[t]{3}{*}{$\begin{array}{l}\text { Circular with } \\
\text { Reinforcement }\end{array}$} & ABNT NBR 8800 & 323,8 & 7,1 & 80 & 5563,45 & 257,8 & 257,8 & 9 & 12,5 & 0,26 & 1060,80 & IA-I \\
\hline & ABNT NBR 16239 & 323,8 & 6,4 & 35 & 3534,47 & 209,9 & 209,9 & 6 & 12,5 & 0,41 & 838,00 & IA-III \\
\hline & EN 1994-1-1 & 323,8 & 6,4 & 40 & 3587,69 & 215,3 & 215,3 & 6 & 10 & 0,42 & 809,60 & IA-IV \\
\hline \multirow{3}{*}{$\begin{array}{l}\text { Square without } \\
\text { Reinforcement }\end{array}$} & ABNT NBR 8800 & 290 & 8 & 90 & 5597,35 & 255,6 & 255,6 & & & 0,33 & 1346,50 & IA-I \\
\hline & ABNT NBR 161239 & 270 & 8 & 40 & 3441,23 & 214,6 & 214,6 & & & 0,55 & 1146,30 & IA-III \\
\hline & EN 1994-1-1 & 260 & 6,4 & 75 & 3873,78 & 180,4 & 180,4 & & & 0,37 & 964,10 & IA-IV \\
\hline \multirow{3}{*}{$\begin{array}{l}\text { Square without } \\
\text { Reinforcement }\end{array}$} & ABNT NBR 8800 & 290 & 8 & 65 & 4896,18 & 267,0 & 267,0 & 4 & 16 & 0,38 & 1371,10 & IA-I \\
\hline & ABNT NBR 16239 & 260 & 8 & 55 & 4069,92 & 209,0 & 209,0 & 4 & 16 & 0,44 & 1216,10 & IA-III \\
\hline & EN 1994-1-1 & 260 & 6,4 & 70 & 3943,11 & 185,7 & 185,7 & 6 & 10 & 0,48 & 1009,50 & IA-IV \\
\hline \multirow{3}{*}{$\begin{array}{l}\text { Rectangular } \\
\text { without } \\
\text { Reinforcement }\end{array}$} & ABNT NBR 8800 & $250: 320$ & 8,8 & 80 & 5067,5 & 290,9 & 235,8 & & & & 1413,50 & IA-I \\
\hline & ABNT NBR 161239 & $200: 250$ & 8 & 40 & 3479,57 & 230,7 & 199,9 & & & 0,54 & 1148,30 & IA-III \\
\hline & EN 1994-1-1 & $240: 280$ & 6,4 & 75 & 3801,71 & 192,0 & 168,4 & & & 0,38 & 963,20 & IA-IV \\
\hline \multirow{3}{*}{$\begin{array}{l}\text { Rectangular with } \\
\text { Reinforcement }\end{array}$} & ABNT NBR 8800 & $250: 320$ & 8 & 80 & 5154,12 & 286,7 & 226,1 & 6 & 12,5 & 0,35 & 1391,10 & IA-I \\
\hline & ABNT NBR 16239 & $240: 280$ & 8 & 45 & 3706 & 219,1 & 193,1 & 4 & 16 & 0,48 & 1191,40 & IA-III \\
\hline & EN 1994-1-1 & $240: 280$ & 6,4 & 80 & 3085,56 & 236,9 & 210,3 & 6 & 10 & 0,48 & 1028,90 & IA-IV \\
\hline
\end{tabular}

Figure 7 shows the results for this example, in similar to fashion to previous analyses.

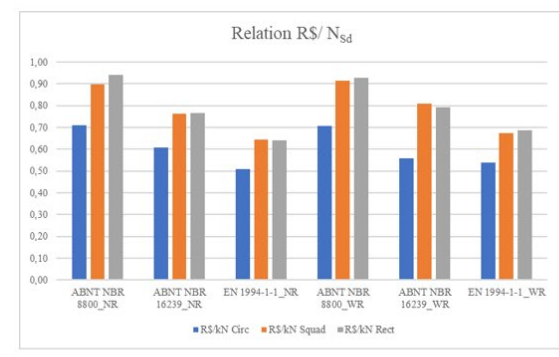

(a)

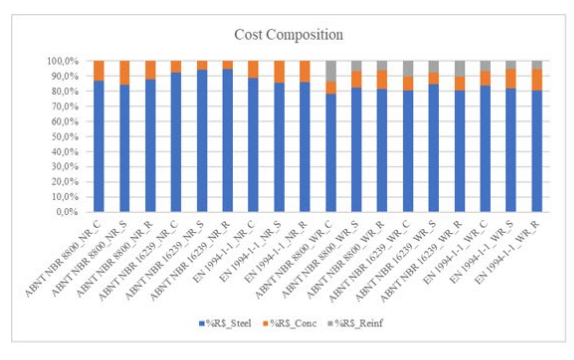

(c)

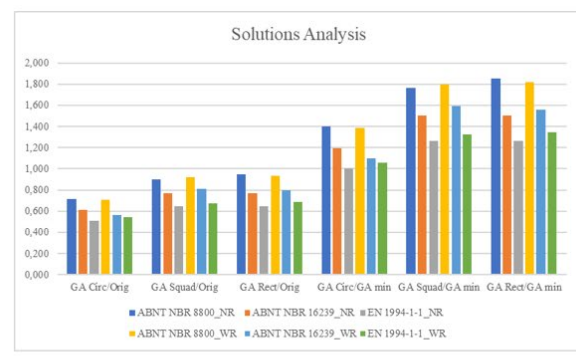

(b)

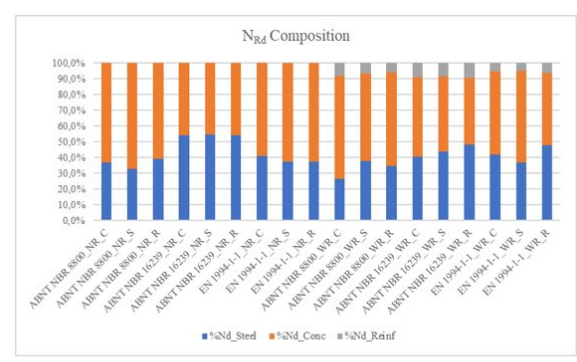

(d)

Figure 7 - (a) Ratio R\$/NSd; (b) Ratio AG/Original Solution; (c) Cost composition of composite filled columns (d) Composition of the resistance to normal forces of the composite filled column. 
Figure 7a shows that the most efficient results are provided by EN 1994-1-1 [3] without reinforcement, while their least efficient counterparts are obtained with ABNT NBR 8800 [1]. The same relation between GA results and the initial solution shown in previous examples is observed here (Figure $7 \mathrm{~b}$ ), meaning that the optimization procedure returned lower values than the original solution for all cases, with the circular column featuring as the best possible solution. Figure 7b shows that the best optimized solution is a result of using EN 1994-1-1 [3] as a basis for design, while ABNT NBR 8800 [1] remains the most conservative approach among all standards.

Following the same logic from previous examples, Figure $7 \mathrm{c}$ and Figure $7 \mathrm{~d}$ show the cost composition and resistance contribution of materials. The steel profile is the largest contributor to the total cost of the columns, but not for their ultimate strength. With the exception of results obtained with ABNT NBR 16239 [2] without longitudinal reinforcement, all methods indicate that concrete and longitudinal steel reinforcement are the most significant contributors to column strength. This behavior is clearly observed in solutions obtained with a ABNT NBR 8800 [1].

\section{CONCLUSIONS}

Results show that the use of concrete with compressive strength $\left(f_{c k}\right)$ larger than $50 \mathrm{MPa}$ is attractive for the cases analyzed herein. More than $70 \%$ of the optimized solutions feature theses values of $f_{c k}$, despite this material presenting a higher financial cost. It is important to note that results might have been different if transportation costs were accounted for. Nonetheless, the added cost would be proportionally included in each solution, as recommended by transportation and assembly manuals provided by CBCA [34]. As such, optimum solutions would remain the same.

It is noted that the design model I from ABNT NBR 8800 [1] governed all cases studied. Thus, this would be the recommended approach for designing the columns should this standard be chosen as a basis for design.

Furthermore, as a general assessment, ABNT NBR 16239 [2] present the best results for designing composite filled columns. This is a result of the latter standard prescribing general design procedures for all types of composite columns, disregarding particularities attributed to the use of tubular steel profiles such as resistance reduction factors for compressive strength and effective flexural stiffness of the columns. As such, ABNT NBR 16239 [2] provides adjustments to take full advantage of the mechanical characteristics of tubular profiles, consequently resulting in less conservative and more economical solutions. The European standard EN 1994-1-1 [3] presents excellent results in comparison with ABNT NBR 8800 [1], possibly due to the latter disregarding effects attributed to concrete confinement in concrete-filled composite tubular columns.

Considering material contributions to cost and axial strength of the columns, all solutions indicate that the structural profile correspond to the larger portion of the total cost of the columns, while high-strength concrete and longitudinal reinforcement presented the largest contributions to column strength. In this case, the optimization procedure implemented was proven as useful during the decision-making process of the structural design. For all cases, GA efficiently indicated the best solutions as those featuring concrete with higher values of $f_{c k}$. Furthermore, due to the structural profile presenting a large impact on financial cost but a relatively small contribution to resistance, if the program intelligently reduces the dimensions of the profile, the solution obtained will always be ideal.

In closure, when adequately implemented, design optimization procedures will always produce better results than traditional design methods. However, as stated by Santoro and Kripka [6] and Tormen et al. [7], additional parameters should be considered in optimization studies, such as the life-cycle analysis of materials and the environmental impacts attributed to their use.

\section{BIBLIOGRAPHY}

[1] Associação Brasileira de Normas Técnicas, Projeto de Estruturas de Aço e de Estruturas Mistas de Aço e Concreto de Edificios Procedimento, ABNT NBR 8800, 2008.

[2] Associação Brasileira de Normas Técnicas, Projeto de Estruturas de Aço e de Estruturas Mistas de Aço e Concreto de Edificações com Perfis Tubulares, ABNT NBR 16239, 2013.

[3] European Commitee for Standardization, Design of Composite Steel and Concrete Structures. Part 1-1: General Rules and Rules for Buildings, EN 1994-1-1: Eurocode 4, 2004.

[4] J. A. Lazzari, E. C. Alvez, and A. F. G. Calenzani, "Dimensionamento otimizado de pórticos em estruturas de aço via algoritmos genéticos," Rev. Estrutura Aco, vol. 9, no. 1, pp. 101-121, 2020.

[5] J. F. I. Oliveira and A. C. O. Miranda, "Structural optimization using multi-objective genetic algorithm," IJERA, vol. 10, no. 1, pp. 112, 2020, http://dx.doi.org/10.9790/9622-1003020112.

[6] J. F. Santoro and M. Kripka, "Minimizing environmental impact from optimized sizing of reinforced concrete elements," Comput. Concr., vol. 25, no. 2, pp. 111-118, 2020, http://dx.doi.org/10.12989/cac.2020.25.2.111. 
[7] A. F. Tormen, Z. M. C. Pravia, F. B. Ramires, and M. Kripka, "Optimization of steel concrete composite beams considering cost and environmental impact," Steel Compos. Struct., vol. 34, no. 3, pp. 409-421, 2020, http://dx.doi.org/10.12989/scs.2020.34.3.409.

[8] S. de Nardin, "Estudo téorico-experimental de pilares mistos compostos por tubos de aço preenchidos com concreto de alta resistência," M.S. thesis, EESC-USP, São Carlos, 1999.

[9] A. P. C. Duarte, N. Silvestre, J. Brito, E. Júlio, and J. D. Silvestre, "On the sustainability of rubberized concrete filled square steel tubular columns," J. Clean. Prod., vol. 170, pp. 510-521, 2018, http://dx.doi.org/10.1016/j.jclepro.2017.09.131.

[10] M. Dundu, "Compressive strength of circular concrete filled steel tube columns," Thin-walled Struct., vol. 56, pp. 62-70, 2012, http://dx.doi.org/10.1016/j.tws.2012.03.008.

[11] P. Gajalakshmi and J. H. Helena, "Behavior of concrete-filled steel columns subjected to lateral cyclic loading," J. Construct. Steel Res., vol. 75, pp. 55-63, 2012, http://dx.doi.org/10.1016/j.jcsr.2012.03.006.

[12] A. Kuranovas, D. Goode, A. K. Kvedaras, and S. Zhong, "Load-bearing capacity of concrete-filled steel columns," J. Civ. Eng. Manag., vol. 15, no. 1, pp. 21-33, 2009, http://dx.doi.org/10.3846/1392-3730.2009.15.21-33.

[13] R. B. Caldas, R. H. Fakury, and J. B. M. Sousa Jr., "Bases do dimensionamento de pilares mistos de aço e concreto segundo o projeto de revisão da ABNT NBR 8800," Rev. Esc. Minas, vol. 60, no. 2, pp. 271-276, 2007, http://dx.doi.org/10.1590/S037044672007000200009.

[14] W. L. A. Oliveira, “Análise teórico-experimental de pilares mistos preenchidos de seção circular,” M.S. thesis, EESC-USP, São Carlos, 2008.

[15] G. S. Papavasileiou, N. Nicolaou, and D. C. Charmpis, "Comparative assessment of buildings with pure steel or steel-concrete composite columns using structural design optimization," in Proc. 4th Eccomas Thematic Conf. Comput. Methods Struct. Dyn. Earthq. Eng., Greece, 2013.

[16] S. Aghdamy, D. P. Thambiratnam, M. Dhanasekar, and S. Saiedi, "Computer analysis of impact behavior of concrete filled steel tube columns," Adv. Eng. Softw., vol. 89, pp. 52-63, 2015, http://dx.doi.org/10.1016/j.advengsoft.2015.06.015.

[17] Z. Tao, Z. Wang, and Q. Yu, "Finite element modelling of concrete-filled steel stub columns under axial compression," J. Construct. Steel Res., vol. 89, pp. 121-131, 2013, http://dx.doi.org/10.1016/j.jcsr.2013.07.001.

[18] H. Thai, B. Uy, M. Khan, Z. Tao, and F. Mashiri, "Numerical modelling of concrete-filled steel box columns incorporating high strength materials," J. Construct. Steel Res., vol. 102, pp. 256-265, 2014, http://dx.doi.org/10.1016/j.jcsr.2014.07.014.

[19] Z.-B. Wang, Z. Tao, L.-H. Han, B. Uy, D. Lam, and W.-H. Kang, "Strength, stiffness and ductility of concrete-filled steel columns under axial compression," Eng. Struct., vol. 135, pp. 209-221, 2017, http://dx.doi.org/10.1016/j.engstruct.2016.12.049.

[20] A. F. Canales, "Estudo do dimensionamento de pilares de aço tubulares e pilares mistos de perfis tubulares preenchidos com concreto de acordo com a ABNT NBR 16239," Undergraduate thesis, UTFPR, Campo Mourão, 2014.

[21] G. S. Papavasileiou and D. C. Charmpis, "Seismic design optimization of multi-storey steel-concrete composite buildings," Comput. Struc., vol. 170, pp. 49-61, 2016, http://dx.doi.org/10.1016/j.compstruc.2016.03.010.

[22] J. Lourenção and E. C. Alves, "Dimensionamento otimizado de pilares mistos preenchidos de aço e concreto," Rev. Port. Eng. Estrut., no. 8, pp. 33-48, Nov 2018.

[23] Y. Pekbey, A. Ozdamar, and O. Sayman, "Buckling optimization of composite columns with variable thickness," J. Reinf. Plast. Compos., vol. 26, no. 13, pp. 1337-1356, 2007, http://dx.doi.org/10.1177/0731684407079772.

[24] J. Brauns and U. Skadins, " On stress-state optimization in steel-concrete composite structures," IOP Conf. Series: Materials Science Eng. ., 2017

[25] A. B. Senouci and M. S. Al-Ansari, "Cost optimization of composite beams using genetic algorithms," Adv. Eng. Softw., vol. 40, no. 11, pp. 1112-1118, 2009, http://dx.doi.org/10.1016/j.advengsoft.2009.06.001.

[26] M.-B. Prendes-Gero, A. Bello-García, J.-J. del Coz-Díaz, F.-J. Suárez-Domínguez, and P.-J. García No., "Optimization of steel structures with one genetic algorithm according to three international building codes," Rev. Constr., vol. 17, no. 1, pp. 47-59, 2018, http://dx.doi.org/10.7764/RDLC.17.1.47.

[27] J. Malveiro, D. Ribeiro, C. Sousa, and R. Calçada, "Model updating of a dynamic model of a composite steel-concrete railway viaduct based on experimental tests," Eng. Struct., vol. 164, pp. 40-52, 2018, http://dx.doi.org/10.1016/j.engstruct.2018.02.057.

[28] C. Liu, A. Hammad, and Y. Itoh, "Multiobjective optimization of bridge deck rehabilitation using a genetic algorithm," Microcomputers Civ. Eng., vol. 12, no. 6, pp. 431-443, 1997, http://dx.doi.org/10.1111/0885-9507.00075.

[29] C. K. Fu, Y. Zhai, and S. Zhou, "Optimum design of welded steel plate girder bridges using a genetic algorithm with elitism," J. Bridge Eng., vol. 10, pp. 291-301, 2005, http://dx.doi.org/10.1061/(ASCE)1084-0702(2005)10:3(291).

[30] M. Z. Abd Elrehim, M. A. Eid, and M. G. Sayed, "Structural optimization of concrete arch bridges using Genetic Algorithms," Ain Shams Eng. J., vol. 10, no. 3, pp. 507-516, 2019, http://dx.doi.org/10.1016/j.asej.2019.01.005.

[31] H. Cho, D. Min, and K. Lee, "Optimum life-cycle design of orthotropic steel deck bridges," Steel Struct., vol. 1, pp. 141-152, 2001.

[32] Associação Brasileira de Normas Técnicas, Projeto de Estruturas de Concreto Armado-Procedimentos, ABNT NBR $6118,2014$. 
[33] Caixa Econômica Federal. Sistema Nacional de Preços e Índices para a Construção Civil. http://www.caixa.gov.br/poderpublico/apoio-poder-publico/sinapi/Paginas/default.aspx (accessed Mar. 27, 2020).

[34] Vallourec Tubos do Brasil, Tubos Estruturais de Seção Circular, Square e Rectangular. Belo Horizonte, 2017, pp. 56. Accessed: Sept. 21, 2020. [Online]. Available: https:/www.famsteel.com.br/blog/catalogos-Tables/catalogo-vallourec-tubos-estruturais/

[35] CBCA, Rev. Constr. Met., vol. 118, 2015.

[36] I. H. Bellei, F. O. Pinho, and M. O. Pinho, Edificios de Múltiplos Andares em Aço, 2a. ed. São Paulo: PINI, 2008.

[37] R. B. Caldas, R. H. Fakury, J. B. M. Souza Jr., PilarMisto 3.04.11: Verificação de Pilares Mistos de Aço e Concreto Segundo a ABNT ABNT NBR 8800 e a ABNT NBR 14323:2010. Belo Horizonte: UFMG, Dep. Eng. Estrut.

Author contributions: JSL: conceptualization, data curation, formal analysis, methodology, writing; PATA: data curation, formal analysis, methodology, writing; GE: formal analysis, writing; ECA: conceptualization, formal analysis, methodology, supervision, writing.

Editors: Túlio Nogueira Bittencourt, Guilherme Aris Parsekian. 